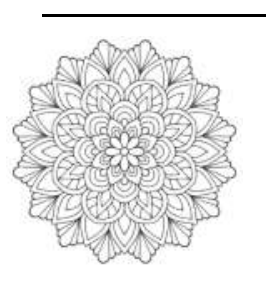

AL HIKMAH: INDONESIAN JOURNAL OF EARLY CHILDHOOD ISLAMIC EDUCATION

ISSN (P): 2550-2200, ISSN (E): 2550-1100,

VOL. 5 (2), 2021, PP. 90 - 111

http://journal.iaialhikmahtuban.ac.id/index.php/ijecie

\title{
PENGEMBANGAN MEDIA BIG BOOK TERHADAP PENGETAHUAN BENCANA BANJIR PADA ANAK USIA 5-6 TAHUN
}

\author{
Ira Agrestin ${ }^{1}$, Eka Cahya Maulidiyah ${ }^{2}$ \\ ${ }^{12}$ Pendidikan Guru Pendidikan Anak Usia Dini, Universitas Negeri Surabaya
}

Meningkatnya aktivitas penduduk dan kebutuhan ruang menjadi masalah tren pembangunan di perkotaan. Banjir bandang menjadi bencana yang mendominasi. Kurangnya pengetahuan akan resiko bencana banjir mengakibatkan anak menjadi kelompok masyarakat paling rentan ketika bencana alam terjadi. Pengetahuan bencana banjir perlu dikenalkan sejak dini, karena bencana telah menjadi kejadian rutin dalam bagian kehidupan sehari-hari. Penelitian pengembangan ini bertujuan untuk mengetahui desain pengembangan media big book dan kelayakan media big book terhadap pengetahuan bencana banjir pada anak usia 5-6 tahun. Penelitian ini menggunakan jenis penelitian R\&D dengan model ADDIE. Penelitian ini terdiri dari (1) Analisis, (2) Perancangan, (3) Pengembangan. Teknik pengumpulan data menggunakan angket. Media big book memuat materi penyebab dan akibat banjir, persiapan sebelum, saat dan sesudah banjir. Kelayakan media ditinjau dari segi materi dan media yang didasarkan pada indikator instrumen penilaian. Berdasarkan analisis hasil dari perhitungan berdasarkan uji validasi oleh ahli materi sejumlah $86,1 \%$ dan ahli media sebesar 95,6\%, hasil tersebut kategori sangat layak. Presentase hasil dari masukan oleh 10 guru PAUD sebagai pengguna media memperoleh hasil 79,6\% termasuk kategori layak. Maka, pengembangan media big book terhadap pengetahuan bencana banjir pada anak usia dini dinyatakan layak sebagai media pembelajaran untuk anak usia dini.

Kata Kunci: Media big book, Banjir, Anak Usia Dini

\section{Abstract}

The increasing activity of the population and the need for space is a problem with the development trend in urban areas. Flash floods become a dominating disaster. Lack of knowledge about the risks of flood disasters makes children the most vulnerable group in society when natural disasters occur. Knowledge of flood disasters needs to be introduced from an early age, because disasters have become a routine occurrence in daily life. This development research aims to determine the design of the big book media development and the feasibility of the big book media on knowledge of flood disasters in children aged 5-6 years. This study uses a type of R\&D research with the ADDIE model. This research consists of (1) analysis, (2) design, (3) development. The data collection technique used a questionnaire. The big book media contains material on the causes and consequences of flooding, preparation before, during and after a flood. The feasibility of the media in terms of material and media is based on the indicators of the assessment instrument. Based on the analysis of the results of calculations based on the validation test by material experts amounting to $86.1 \%$ and media experts by $95.6 \%$, these results are very feasible category. The percentage of results from input by 10 PAUD teachers as media users obtained results of $79.6 \%$, including the feasible category. Thus, the development of the big book media on knowledge of flood disasters in early childhood is deemed appropriate as a learning medium for early childhood.

Keywords: Big Book Media, Flood, Early Childhood 


\section{PENDAHULUAN}

Indonesia sebagai wilayah yang beriklim tropis terdiri dari musim penghujan dan musim kemarau. Indonesia merupakan negara dengan tingkat kerawanan bencana tertinggi. Hal ini di karenakan Indonesia secara geografis terletak di garis khatulistiwa. Maka, pada saat musim kemarau rawan akan terjadi kebakaran hutan dan kekeringan lahan, sedangkan pada saat musim penghujan apabila curah hujan tinggi. Kondisi ini akan memicu terjadinya banjir dan tanah longsor. "Wilayah di seluruh Indonesia terdapat sedikitnya 5.590 sungai induk dan 600 di antaranya berpotensi menimbulkan banjir. Daerah rawan banjir mencapai 1,4 hektar" (Achmad Yurianto, 2016).

Data Inarisk R.Hadianto Wardjaman dkk, (2018) menjelaskan jenis bencana yang mendominasi antara tahun 2005-2015 merupakan bencana hidrometeorologis, salah satunya adalah banjir dan banjir bandang. Risiko luas bahaya banjir memiliki angka yang cukup tinggi dibandingkan dengan risiko luas bahaya yang disebabkan oleh banjir bandang. Risiko luas bahaya banjir mencapai 39.371.167 (Ha) beserta potensi jiwa yang terdampak kurang lebih 100.814.666. Hal tersebut memungkinkan adanya dampak kerusakan fisik sebesar 176.329.82 milyar rupiah, kerusakan ekonomi 140.520.440 milyar rupiah dan kerusakan lingkungan 12.135.957 (Ha). Sedangkan bahaya luas banjir bandang tercatat sekitar $2.733 .966(\mathrm{Ha})$ dengan potensi jumlah angka masyarakat terdampak mencapai 8.637.161. Oleh karena itu, terjadi kerusakan fisik sebesar 44.679.539 milyar rupiah, kerusakan ekonomi mencapai angka 15.358.006 dan kerusakan lingkungan 1.056.365 (Ha)".

Pusat Data Informasi Komunikasi BNBP (2020) merilis update sebaran kejadian bencana alam di Indonesia periode 1 Januari- 16 November 2020 No: 326/U205/BenIndonesia/BNPB/16112020 melalui laman resmi twitter BNPB_Indonesia. Badan Nasional Penanggulangan Bencana (BNPB) menjelaskan bahwa sampai tanggal 16 November 2020 pukul 15.00 WIB, telah tercatat jumlah kejadian bencana sebanyak 2.551 kejadian. Kejadian bencana alam mendominasi adalah bencana banjir, diikuti berturut- turut puting beliung dan tanah longsor. Total jiwa terdampak bencana alam sejumlah 5.545 .827 jiwa, sedangkan 350 jiwa kehilangan nyawa dan hilang dan 499 jiwa mengalami luka-luka.

Banjir dapat dikatakan sebagai bencana, hal ini juga tidak lepas dari salah satu masalah tren pembangunan di perkotaan khususnya negara berkembang. Daerah terbesar di negara Indonesia yang tidak pernah luput dari bencana banjir adalah perkotaan. Kota Surabaya merupakan salah satu daftar perkotaan yang tidak luput dari bencana banjir. Kota Surabaya menjadi bagian penting bagi Provinsi Jawa Timur. Kota Surabaya adalah ibu kota Provinsi 
Jawa Timur. Tentunya, kota Surabaya memiliki peran yang cukup strategis pada skala nasional.

Kota Surabaya sebagai pusat perdagangan, jasa dan transportasi darat, laut serta udara baik secara nasional maupun internasional. Peran strategis tersebut menyebabkan adanya pembangunan dari berbagai sektor sebagai penunjang pertumbuhan ekonomi. Di sisi lain, dengan adanya pembangunan dari berbagai sektor menimbulkan permasalahan baru salah satunya permasalahan banjir. Meningkatnya pembangunan berdampak pada perubahan tata guna lahan dan lingkungan. Hal ini mengakibatkan terjadinya penurunan terhadap kualitas ekosistem. Penyebabnya dipengaruhi oleh adanya peningkatan kebutuhan ruang karena meningkatnya pertumbuhan penduduk dan aktivitas dalam ruang.

Faktor penyebab banjir di kota Surabaya adalah faktor minimnya resapan air dan sampah. Hal ini dapat dibuktikan dengan pernyataan "Kepala Badan Penanggulan Bencana dan Perlindungan Masyarakat (BPB Linmas) dan wakil DPRD Surabaya Christijanto dan Mufida bahwa banjir terjadi karena sampah yang di buang sembarangan, sehingga mengganggu pelaluan air di Jalan Mojopahit Surabaya dan lokasi lainnya. Oleh karena itu, dihimbau kepada masyarakat untuk tidak buang sampah sembarangan. Banjir yang terjadi di kawasan Kendangsari akibat saluran air atau box culvert dipenuhi tumpukan sampah"(Melani, 2020).

Dampak dari adanya kondisi tersebut anak- anak menjadi masyarakat yang paling rentan ketika bencana alam terjadi. Salah satu tingginya risiko bencana yang dialami oleh anak- anak karena ketidakpahaman akan bencana itu sendiri. Pernyataan tersebut diperkuat oleh "TIM Pengabdian Masyarakat Universitas Indonesia Peduli Bencana mengatakan bahwa anak- anak menjadi bagian kelompok masyarakat yang paling rentan ketika bencana alam terjadi. Selama ini, anak - anak tidak memahami akan potensi bencana itu sendiri. Meskipun, buku saku bencana memang telah ada dan dapat di unduh di laman resmi Badan Nasional Penanggulangan Bencana (BNPB). Sayangnya, buku saku tersebut tidak dibuat untuk anakanak. Hal itu disebabkan karena ketidakmampuan anak memahami kosa kata dan kalimat dalam buku saku bencana yang bersifat teknis dan sulit dipahami, sehingga hanya orang dewasa yang dapat memahaminya" (Harsono, 2019).

Pentingnya anak mendapatkan pengetahuan tentang bencana banjir sebagai upaya preventif yang bersifat penting dan mendasar bagi kehidupan sehari- hari anak untuk mengurangi risiko bencana yang dihadapi. Beberapa wilayah perkotaan di Surabaya, kondisi banjir menjadi bagian dari kehidupan sehari- hari. Kejadian tersebut berlangsung lama dan telah menjadi kejadian rutin. Maka, pengetahuan bencana banjir pada anak usia dini sangat 
Eka Cahya Maulidyah, Ira Agrestin (Pengembangan Media Big Book)

penting diberikan agar ketika terjadi bencana banjir terjadi anak memiliki kemampuan untuk bertahan sekaligus melindungi diri dari bencana baik untuk diri sendiri maupun orang yang berada di sekitarnya. Dampak jika anak tidak mendapatkan pengetahuan tentang bencana banjir, maka anak tidak tahu apa saja yang diperlukan baik sebelum, ketika atau saat terjadi bencana banjir. Keterbatasan pemahaman tentang risiko bencana, dimana bencana secara tidak langsung telah menjadi bagian dari kehidupan mereka menyebabkan anak menjadi kelompok paling rentan terdampak bencana banjir. Masalah kecemasan dan gangguan fisik, mental, emosi serta perilaku dan spiritual banyak terjadi pada anak- anak.

UU No.24 Tahun 2007 tentang penanggulangan bencana berbunyi "Kesiapsiagaan bencana merupakan proses membentuk individu dari aspek pengetahuan, sikap, dan keterampilan menghadapi ancaman yang terdiri dari tindakan pencegahan dan penanggulangan guna menumbuhkan perilaku atau mental sadar terhadap bencana (mengerti dan memahami tentang bencana itu sendiri). Pendidikan siaga bencana terintegrasi ke dalam program pembangunan yaitu sektor pendidikan. Jalan menuju mental sadar bencana melalui jalur pendidikan sejak dini”(Purwani \& Fridani, 2019).

Taman kanak-kanak merupakan jalur pendidikan formal pendidikan anak usia dini yang menyelenggarakan pendidikan bagi anak usia 4-6 tahun yang merupakan masa peka bagi anak untuk meletakkan dasar pendidikan pertama dalam mengembangkan kemampuan fisik, kognitif, bahasa, sosial emosional, konsep diri, disiplin, kemandirian, seni, moral dan nilai agama-agama (Bidang, 2003). Maka sejak usia dini, anak- anak seharusnya menerima pembelajaran tentang bencana. Kegiatan pembelajaran tentang bencana meliputi menilai, merencanakan, mengimplementasikan, memantau, dan mengevaluasi serta mempengaruhi teori dan praktik (Arifianti, 2012). Pembelajaran ini diberikan secara sistematis dan berkesinambungan. Salah satu upaya yang dapat diberikan dalam bekal pengetahuan sadar bencana melalui pemberian fasilitas berupa media pembelajaran yang dapat memudahkan guru dalam mengajarkan bencana banjir kepada anak- anak di sekolah. Menurut Setiyaningsih \& Syamsudin (2014) berpendapat bahwa media adalah sesuatu yang bersifat menyalurkan pesan dan dapat merangsang pikiran, perasaan, dan kemauan anak, sehingga dapat mendorong terjadinya proses belajar. Media berasal dari kata dalam bahasa latin, yang merupakan bentuk jamak dari kata medium. Media secara harfiah berarti "perantara" atau "pengantar". Sedangkan dalam bahasa arab kata perantara disebut kata bentuk jamak. Jadi secara bahasa media adalah pengantar pesan dari pengirim kepada penerima pesan (Andini, 2020). 
Eka Cahya Maulidyah, Ira Agrestin (Pengembangan Media Big Book)

Ayu et al. (2020) menjelaskan secara khusus tentang pengertian media dalam proses belajar- mengajar. Media dapat diartikan sebagai alat- alat grafis, photografis atau elektronis untuk menangkap, memproses dan menyusun kembali visual atau verbal. Media pembelajaran merupakan kategori dari alat yang sengaja dibuat dengan maksud untuk mencapai suatu tujuan yaitu menyampaikan sebuah pengetahuan atau pemahaman yang berkaitan dengan sebuah pesan untuk mempermudah penerima pesan sebagaimana dengan tujuan dibuatnya media pembelajaran itu sendiri (Maulidiyah \& Chamim, 2020). Adam \& Syastra (2015) media pembelajaran adalah segala sesuatu yang bisa merangsang atau menstimulus terjadinya suatu proses pembelajaran. Pendapat lain menjelaskan tentang macam- macam media yang dapat digunakan dalam proses pembelajaran meliputi suara langsung, rekaman audio, pembelajaran terprogram, papan tulis, media cetak, film rangkai, media transparansi, dan gambar (Mujiani, 2016).

Berdasarkan pendapat di atas dapat disimpulkan bahwa media merupakan sistem informasi berisi pesan sebagai perantara atau alat bantu untuk memproses terjadinya proses pembelajaran baik berupa visual atau verbal. Tentunya, dalam setiap proses pembelajaran pada anak usia dini tidak terlepas dari media atau sumber belajar yang berkaitan dengan kehidupan sehari- harinya. Anak usia dini belajar melalui apa yang di dengar, dilihat dan dilakukanya. Pendidik wajib menyediakan media sesuai tahapanya untuk proses pembelajaran berjalan secara optimal dengan memperhatikan pencapaian perkembangan dan pertumbuhan secara optimal.

Maka dari itu salah satu media pembelajaran yang dapat menunjang proses pembelajaran dan bersifat menarik anak usia dini adalah media big book. Media big book dipilih karena buku ini memiliki perbedaan dibandingkan buku cerita lainnya. Keunggulan big book dalam segi ukuran memiliki ukuran yang lebih besar dari pada buku bergambar pada umumnya dan segi alur cerita yang cukup singkat serta mudah dipahami.

Selain itu, big book memiliki pola kalimat yang jelas serta berulang dan ukuran huruf yang cukup besar guna memudahkan ketika dibaca di kelas. Beberapa pendapat para ahli di antaranya (Colville-hall \& Oconnor, 2006) big books typically use predictable texts, allowing readers to use their prior knowledge to identify word that come next in a sentence, as well as rhythm, ryhme, and repition, all of wich aid word recognition and identification. Berdasarkan definisi di atas menjelaskan bahwa big book dapat digunakan pada kelas awal dimana topik dan isinya dapat disesuaikan dengan minat anak atau tema pembelajaran. Selain itu, big book juga memberikan kemudahan bagi anak pada kelas awal untuk belajar mengenal dan

94 AL HIKMAH: INDONESIAN JOURNAL OF EARLY CHILDHOOD ISLAMIC EDUCATION |VOL.5 No.2 Tahun 2021 
mengidentifikasi (mencari, menemukan, mengumpulkan) segala sesuatu yang berkaitan dengan pembelajaran yang disampaikan oleh pendidik. Brown dalam (Setiyaningsih \& Syamsudin, 2014) menjelaskan tentang pengertian media big book ialah buku berukuran besar dengan ilustrasi penuh warna yang dapat digunakan guru untuk menyampaikan cerita dalam suatu kelas.

Menurut Jalongo dalam (Ayu et al., 2020) dalam pendapatnya menyatakan ukuran big book harus mempertimbangkan segi keterbacaan dan jumlah anak dalam setiap kelas. Setiap halaman dalam big book berukuran 24 inchi x 36 inchi $(61 \mathrm{~cm}$ x 91,5cm $)$. Berbeda dengan pendapat Solehuddin dalam (Setiyaningsih \& Syamsudin, 2014) big book umumnya berukuran $40 \mathrm{~cm}$ x $60 \mathrm{~cm}$, sedangkan Susanti et al., (2020) berpendapat mengenai jumlah halaman yang terdapat pada big book 10-15 halaman.

Ditinjau dari segi karakteristik Novita Rahmawati Aditya NPM., (2020) mengatakan ukuran big book beragam jenisnya mulai dari ukuran A3, A4, A5 atau seukuran koran dan harus mempertimbangkan segi keterbacaan siswa jika di dalam kelas. Big book memiliki karakteristik khusus yaitu warna - warni, gambar menarik, kata yang dibuat berulang, memiliki plot yang mudah ditebak serta memiliki pola berirama untuk dinyanyikan. "As mentioned earlier, the distinguishing feature of the Big Book is of course its size. It is usually about 18 to 20 inches tall and the print is at least an inch high. The size and clarity of the print and illustrations help to ensure that all the children in the class are able to focus on the book from a distance of at least 15 feet big book" (Nambiar, 1993). Berdasarkan pernyataan tersebut menjelaskan bahwa big book memiliki tinggi sekitar 18 hingga 20 inchi dan tinggi cetakan setidaknya 1 inchi. Ukuran dan kejelasan cetakan atau ilustrasi membantu memastikan bahwa semua anak di kelas dapat fokus pada buku dari kejauhan setidaknya 15 kaki.

Media big book memiliki keistimewaan dibanding buku cerita pada umumnya karena dari segi ukuran lebih besar. Ukuran yang lebih besar bertujuan agar dapat menjangkau semua anak di kelas. Big book memiliki pola kalimat dan alur cerita yang bersifat sederhana. Gambargambar yang mengilustrasikan kalimat serta ukuran huruf yang besar. Hal ini bertujuan untuk memberikan kemudahan saat anak membaca bersama guru atau mandiri. Selain itu, guru memiliki kesempatan untuk melakukan kegiatan tanya jawab dengan anak terkait isi dalam big book. Tanya jawab dimaksudkan agar topik bacaan semakin berkembang sesuai dengan pengalaman dan imajiasi anak dengan melibatkan anak pada situasi nyata tanpa cara menakutkan (Andini, 2020). 
Hasil dari beberapa penelitian terkait dengan media big book dilakukan oleh (Andini, 2020) tentang pengembangan media big book sebagai media pengembangan karakter pada anak usia dini. Penelitian sejenis juga dilakukan oleh (Kiromi \& Fauziah, 2016) tentang pengembangan media big book untuk pembentukan karakter anak usia dini. Selain itu penelitian yang sama terkait dengan media big book untuk meningkatkan kemampuan berbahasa dilakukan oleh (Fatriani \& Samadhy, 2018) tentang pengembangan media big book terhadap keterampilan membaca permulaan dengan metode suku kata..

Selanjutnya, beberapa penelitian terkait dengan bencana banjir sebelumnya telah dilakukan oleh (Wibowo et al., 2017) tentang disaster mitigation pop up book sebagai media pembelajaran mitigasi bencana berbasis kearifan lokal bagi siswa sekolah dasar. Selain itu, penelitian oleh (Hanifah, 2017) tentang pengembangan media pop up book materi bencana banjir untuk meningkatkan pemahaman konsep siswa kelas 1 MIN Sukosewu Gandusari Kab. Blitar

Hasil dari penelitian sebelumnya, masih belum ditemukanya pengembangan media big book untuk pembelajaran bencana banjir pada anak usia dini. Media big book dapat memberikan bantuan kepada anak untuk belajar mengenal dan mengidentifikasi segala sesuatu yang berkaitan dengan pembelajaran yang disampaikan oleh pendidik, salah satunya untuk menambah pengetahuan bencana banjir. Oleh karena itu, peneliti berinovasi mengembangkan media big book untuk pengetahuan bencana banjir. Berdasarkan identifikasi masalah di atas, adapun penelitian ini bertujuan untuk mengetahui desain pengembangan produk media big book dan mengetahui kelayakan pengembangan media big book terhadap pengetahuan bencana banjir pada anak usia 5-6 tahun.

\section{METODE}

Penelitian ini menggunakan jenis penelitian yaitu penelitian dan pengembangan (Research \& Development) dengan model pengembangan Analysis, Design, Development, Implementation, Evaluation (ADDIE). Sugiyono (2016) menyatakan bahwa Research \& Development (R\&D) adalah metode penelitian yang digunakan untuk menghasilkan sebuah produk tertentu guna menguji keefektifan atau kelayakan produk tersebut. Sezzer dalam (Saroinsong et al., 2020) menjelaskan bahwa model pengembangan Analysis, Design, Development, Implementation, Evaluation (ADDIE) adalah pendekatan yang menekankan pada analisa, dimana pada setiap komponen di dalamnya saling berinteraksi satu dengan yang lain dan berkordinasi serta terkait sesuai dengan fase yang ada.

96 AL HIKMAH: INDONESIAN JOURNAL OF EARLY CHILDHOOD ISLAMIC EDUCATION |VOL.5 No.2 Tahun 2021 
Menurut (Sari, n.d.) model pengembangan ADDIE merupakan suatu model desain pembelajaran yang bersifat ke arah generik. Pemilihan model ADDIE dalam pengembangan media big book bertema bencana banjir karena model pengembangan ADDIE mudah diterapkan dan memiliki langkah yang bersifat sederhana dalam mengembangkan suatu produk untuk memecahkan masalah yang berkaitan dengan pengetahuan sesuai dengan pengembangan produk media big book terhadap pengetahuan bencana banjir. Langkahlangkah model pengembangan ADDIE sebagai berikut :

Gambar 1. Langkah-Langkah model pengembangan ADDIE

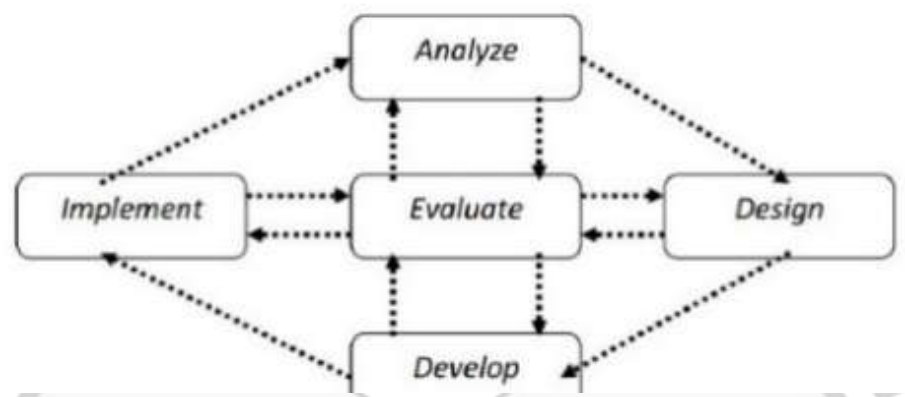

Sumber: (Pudjawan, 2015)

Dick \& Carey dalam (Sari, n.d.) mengembangkan model ADDIE, adapun langkahlangkah penerapan model ADDIE dalam penelitian ini sebagai berikut:

a) Analysis, tahap ini merupakan tahap menganalisis potensi masalah-yang dapat terjadi karena model/metode yang ada tidak sesuai dengan kebutuhan karakteristik peserta didik, lingkungan, teknologi. Proses analisis dapat dilakukan melalui menjawab pertanyaan berikut: 1) Apakah model/metode baru dapat mengatasi permasalahan yang dihadapi?; 2) Apakah guru dapat menerapkan model/metode baru?,

b) Design, tahap desain atau rancangan yaitu merancang suatu rancangan yang bersifat konseptual dan menjadi dasar pada proses berikutnya. Tahapan sistematik dari tahap desain meliputi: 1) Menetapkan tujuan pembelajaran; 2) Menemukan gagasan baru; 3) Menyusun instrumen 4) Menyiapkan prototipe atau perancangan produk,

c) Development, tahap pengembangan berisikan kegiatan realisasi rancangan produk yang bersifat konseptual menjadi produk yang siap di implementasikan

d) Implementation, Tahap ini merupakan implementasi rancangan yang telah dikembangkan dan dilaksanakan dengan mengacu pada tujuan kegiatan yang telah ditetapkan sebelumnya,

e) Evaluate,tahap evaluasi digunakan untuk memberi umpan balik pada penerapan rancangan berikutnya. Batasan masalah dalam penelitian ini hanya dilakukan 
Batasan masalah dalam penelitian ini hanya dilakukan sampai tahap pengembangan produk (development). Tahap ini dipilih berdasarkan pertimbangan di masa pandemi covid19, sehingga pengembangan tidak dapat diimplementasikan ke TK secara langsung. Sumber data yang digunakan dalam penelitian adalah sumber data sekunder. Sumber data sekunder yaitu data- data yang di dapatkan dari penelitian terdahulu yang bersifat relevan.

Tahap pengembangan (Development) merupakan tahap yang bertujuan untuk menjelaskan bagaimana pengembangan media big book dan menjelaskan kelayakan media big book terhadap bencana banjir. Tahap ini bertujuan untuk menguji kelayakan produk media big book terhadap bencana banjir. Uji kelayakan media hanya terbatas pada validasi oleh ahli materi dan ahli media. Ahli materi dan ahli media merupakan dosen jurusan PGPAUD Fakultas Ilmu Pendidikan Universitas Negeri Surabaya serta 10 guru PAUD yang telah memenuhi kriteria untuk memberikan masukan dan saran agar penggunaan produk media lebih sesuai secara praktis. Proses validasi bertujuan untuk mengetahui kelayakan pengembangan produk media big book dalam menambah pengetahuan bencana banjir pada anak dengan mempertimbangkan masukan para ahli dan guru sebagai bahan perbaikan.

Teknik pengumpulan data menggunakan angket dengan instrumen berupa lembar validasi dari ahli media dan ahli materi. Instrumen sebelumnya telah divalidasi secara teoritik dengan di konsultasikan dengan dosen pembimbing penelitian. Angket yang diberikan kepada guru berupa google form yang telah di tautkan link video media big book berisi tentang langkahlangkah penggunaan dan spesifikasi produk.

Oleh karena itu, dalam penyusunan kisi- kisi instrumen pengembangan produk media big book terhadap bencana banjir untuk ahli media bersumber dari penelitian tentang Pengembangan Media Buku Cerita dalam Pembelajaran Toilet Training (Asfarina, 2018) yang telah di mofidikasi sesuai dengan kebutuhan penelitian. Instrumen yang digunakan oleh ahli media untuk memberikan kelayakan media berisi tentang indikator penilaian desain produk media big book. Sedangkan instrumen validasi untuk ahli materi berisi tentang indikator materi banjir yang bersumber dari penelitian terdahulu tentang Pengaruh Pengetahuan dan Sikap tentang Resiko Bencana Banjir terhadap Kesiapsiagaan Remaja usia 15-18 tahun dalam menghadapi Bencana Banjir di Kelurahan Pedurungan Kidul Kota Semarang (Purwoko, 2015) dan (Peraturan Menteri Pendidikan No.137 2014) di modifikasi sesuai dengan kebutuhan penelitian.

Analisis data menggunakan teknik analisis data kualitatif dan data kuantitatif. Data kualitatif yang diperoleh dari masukan validator pada tahap validasi sebagai bahan perbaikan 
produk media saat proses pengembangan media big book terhadap pengetahuan bencana banjir pada anak usia 5-6 tahun. Sedangkan, data kuantitatif adalah hasil penilaian angket tentang tingkat kelayakan media big book terhadap pengetahuan bencana banjir. Angket di olah secara presentase dengan skala likert. Adapaun, skala ini disusun dalam bentuk pernyataan yang telah disusun berdasarkan instrumen penelitian yang bersumber dari penelitian yang telah dilakukan sebelumnya dan diikuti empat respon sebagai berikut:

Tabel 1. Skala Likert

\begin{tabular}{ccc}
\hline No & $\begin{array}{c}\text { Analisis } \\
\text { Kuantitatif }\end{array}$ & Skor \\
\hline 1. & Tidak Setuju & 1 \\
\hline 2. & Kurang Setuju & 2 \\
\hline 3. & Setuju & 3 \\
\hline 4. & Sangat setuju & 4 \\
\hline
\end{tabular}

(Sumber: Nurlaela, 2018)

Nilai yang diberikan antara 1 sampai 4 untuk respon tidak setuju, kurang setuju, setuju dan sangat setuju menjelaskan posisi sangat negatif ke posisi sangat positif. Respon netral sengaja dihilangkan, agar responden dapat menunjukkan sikap atau pendapatnya terhadap pernyataan dalam angket. Skala dalam penelitian ini menggunakan interval, sehingga dapat dianalisa dengan menghitung rata- rata jawaban berdasarkan skoring setiap jawaban responden. Hasil dari skor penilaian yang diberikan oleh ahli media dan ahli materi dicari rata- ratanya dan dikonversikan menjadi pernyataan penilaian. Pernyataan penilaian tersebut dapat dilihat dalam tabel sebagai berikut:

Tabel 2. Kriteria Kelayakan dan Keefektifan Produk Media

\begin{tabular}{cc}
\hline Skor Persentase $\%$ & Interpretasi \\
\hline $\mathrm{P}>80 \%$ & Sangat layak \\
\hline $61 \%<\mathrm{P} \leq 60 \%$ & Layak \\
\hline $41 \%<\mathrm{P} \leq 40 \%$ & Cukup layak \\
\hline $20 \%<\mathrm{P} \leq 40 \%$ & Kurang layak \\
\hline $\mathrm{P} \leq 20 \%$ & Sangat kurang layak \\
\hline
\end{tabular}

(Sumber: Nurlaela, 2018)

Kelebihan dari produk media big book bertema bencana banjir yaitu menambah pengetahuan bencana banjir pada anak karena banjir telah menjadi bagian dari kehidupan

99 AL HIKMAH: INDONESIAN JOURNAL OF EARLY CHILDHOOD ISLAMIC EDUCATION |VOL.5 No.2 Tahun 2021 
Eka Cahya Maulidyah, Ira Agrestin (Pengembangan Media Big Book)

serta menjadi kejadian rutin di kehidupan perkotaan. Sehingga, ketika anak memiliki pengetahuan dasar sederhana tentang banjir, diharapkan mampu melindungi diri atau orang lain di sekitarnya. Selain itu, media big book memiliki kelebihan bagi guru ketika digunakan di kelas karena ukuran huruf dan bentuk yang lebih besar dari umumnya mampu menjangkau seluruh anak di kelas serta memiliki pola kalimat yang bersifat sederhana. Adapun spesifikasi produk media big book bencana banjir yang akan dikembangkan sebagai berikut:

\begin{tabular}{|c|c|c|}
\hline No & $\begin{array}{c}\text { Rincian } \\
\text { Pengembangan }\end{array}$ & Keterangan \\
\hline 2. & $\begin{array}{l}\text { Ukuran, halaman da } \\
\text { warna produk }\end{array}$ & 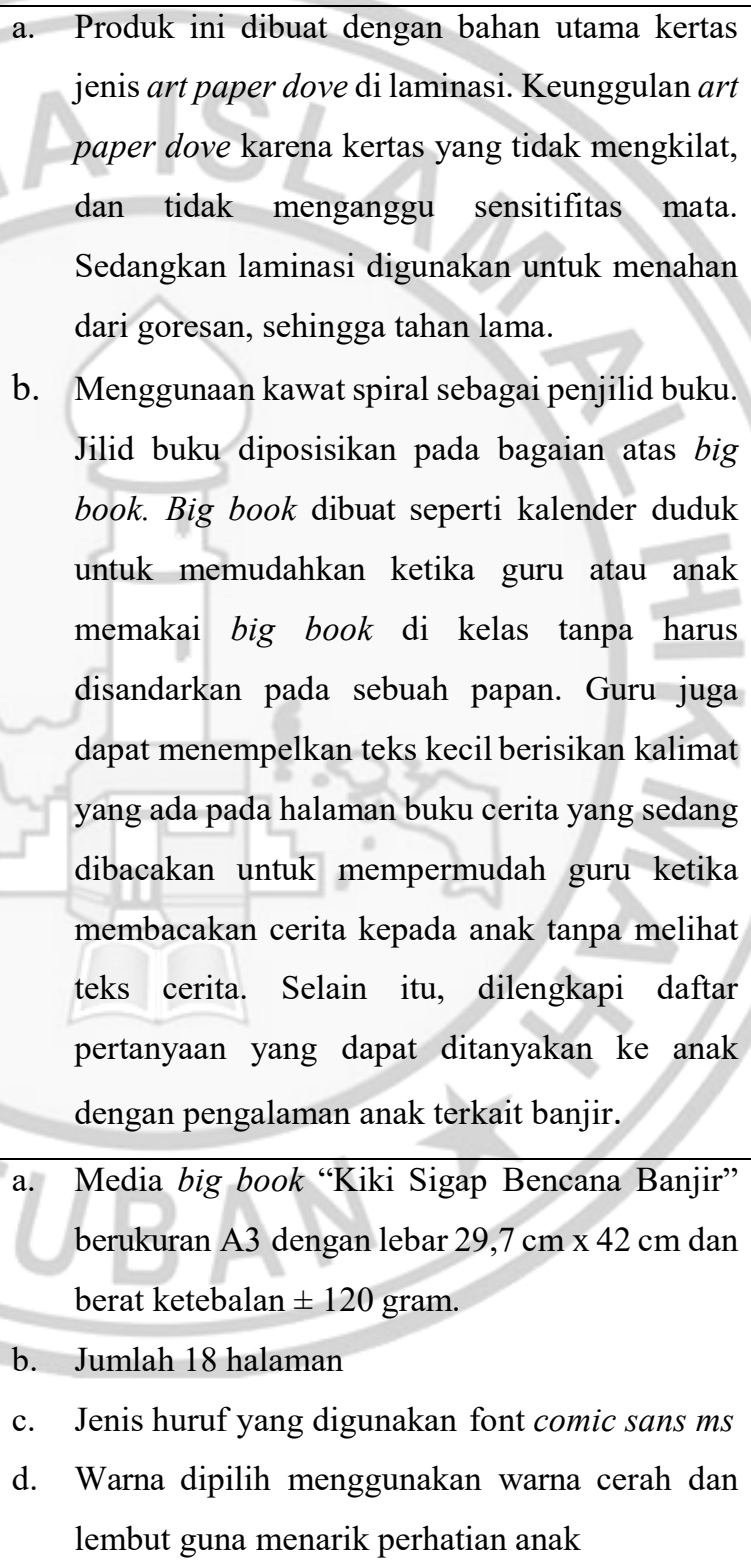 \\
\hline 3. & Cover & $\begin{array}{l}\text { "Kiki Sigap Bencana Banjir" dengan gambar cover } \\
\text { yang menggambarkan tokoh Kiki bersama ayah dan } \\
\text { ibu menghadapi bencana banjir. }\end{array}$ \\
\hline
\end{tabular}


Isi media big book bercerita tentang Keluarga kiki

yaitu ayah, ibu, dan kiki sedang melihat acara berita tentang banjir di TV. Kiki bertanya kepada ayahnya tentang apakah banjir itu, dan bagaimana bisa terjadi banjir serta dampak apa yang terjadi jika terjadi banjir. Selain itu Kiki juga bertanya apa saja yang dilakukan saat banjir dan setelah banjir. Ayah menjawab semua pertanyaan kiki jika banjir merupakan bencana alam yang disebabkan karena ulah manusia dan alam. Jika terjadi banjir akan kehilangan harta, benda dan keluarga. Banjir dapat 4. Isi dicegah dengan membersihkan saluran air dan membuang sampah pada tempatnya. Persiapan ketika banjir dijelaskan bahwa Ibu memberitahu Kiki apa saja yang dipersiapkan ketika terjadi banjir adalah tas siaga banjir, mematikan saklar listrik dan menelfon kepala desa apabila air meninggi. Setelah banjir hal yang dilakukan adalah membersihkan rumah dengan antiseptik, mengeluarkan semua perabotan yang terendam banjir dan dijemur dibawah sinar matahari, selanjutnya mengeringkan peralatan listrik yang terndam air. Kemudian, melaporkan kerugian kepada kepala desa.

\section{HASIL DAN PEMBAHASAN}

\section{Hasil}

Pengembangan media big book terhadap pengetahuan bencana banjir sesuai dengan prosedur dan tahapan model pengembangan ADDIE (Analyze, Design, Development, Implementation, Evaluation). Penelitian dijelaskan menurut langkah- langkah dari tahapan model ADDIE. Model ADDIE dipilih karena model pengembangan ini memiliki memiliki langkah-langkah yang sederhana, sehingga mudah diterapkan dalam mengembangkan suatu produk penelitian. Model ADDIE dalam penelitian ini terbatas sampai pada tiga tahapan yaitu analisis (analyze) merupakan tahapan menganalisis potensi masalah yang dapat terjadi karena model/metode yang ada tidak sesuai dengan kebutuhan karakteristik peserta didik, lingkungan, teknologi. Proses analisis dapat dilakukan melalui menjawab pertanyaan berikut: a) Apakah model/metode mampu mengatasi masalah yang dihadapi? Penggunaan media big 
book terhadap pengetahuan bencana banjir pada anak usia 5-6 tahun diharapkan mampu mengatasi permasalahan yang dihadapi yaitu keterbatasan pemahaman tentang risiko bencana banjir baik sebelum, ketika atau saat terjadi banjir dan setelah terjadi banjir. Sedangkan, banjir secara tidak langsung telah menjadi bagian dari kehidupan mereka.; b) Apakah guru dapat menerapkan model/metode baru? Pengembangan media big book memberikan bantuan kepada anak pada kelas awal untuk belajar mengenal dan mengidentifikasi (mencari, menemukan, mengumpulkan) segala sesuatu. Big book memudahkan pendidik menyampaikan pembelajaran yang dapat disesuaikan dengan tema pembelajaran atau minat anak. Selain itu, memiliki ilustrasi penuh warna, pola kalimat sederhana, serta ukuran besar, sehingga mampu menjangkau seluruh anak di kelas.

Selanjutnya, tahap kedua perancangan (design) yaitu merancang suatu rancangan yang bersifat konseptual. Tahap ini menjadi dasar pada proses berikutnya. Tahapan sistematik dari tahap desain meliputi: a) Menetapkan tujuan pembelajaran yaitu anak dapat mengetahui situasi bahaya yang ada di sekitarnya yaitu banjir dan anak dapat mengatasi permasalahan yang dihadapi dari risiko bencana banjir baik sebelum, ketika dan setelah terjadi banjir, b) Menenemukan gagasan baru tentang teori media big book melalui jurnal dan penelitian terdahulu, membandingkan keunggulan media big book dengan media lainnya, sebelum menentukan media yang cocok untuk mengatasi permasalahan yang ada di sekitar yaitu banjir, c) Menyusun instrumen media big book terhadap bencana banjir disusun dengan bersumber dari penelitian tentang Pengembangan Media Buku Cerita dalam Pembelajaran Toilet Training (Asfarina, 2018) dan penelitian tentang Pengaruh Pengetahuan dan Sikap tentang Resiko Bencana Banjir terhadap Kesiapsiagaan Remaja usia 15-18 tahun dalam menghadapi Bencana Banjir di Kelurahan Pedurungan Kidul Kota Semarang (Purwoko, 2015: 81-83) serta Peraturan Menteri Pendidikan No.137 (2014) yang telah di kembangkan terlebih dahulu, d) Menyiapkan prototipe (perancangan produk) yaitu menentukan bahan yang sesuai produk media big book dengan mempertimbangkan keawetan dan kepraktisan, menentukan ukuran yang sesuai dengan teori yang telah ditemukan dan pemilihan warna serta desain ilustrasi untuk menarik perhatian anak. Selain itu, menentukan isi materi cerita dengan berpedoman Achmad Yurianto, (2016) dan Supartini et al., (2017) tentang kesiapan menghadapi banjir yang telah disesuaikan dengan karakteristik anak usia 5-6 tahun.

Tahap pengembangan (development) berisikan kegiatan realisasi rancangan produk yang bersifat konseptual menjadi produk yang siap diimplementasikan. Tahap pengembangan dari media big book terletak pada pengembangan tema yang dapat diterapkan pada pembelajaran 
tema alam semesta dengan sub tema gejala alam yaitu banjir. Anak dapat terstimulasi dengan mengenali dan merepresentasikan beberapa kata- kata dan gambar- gambar dalam materi yang disajikan pada media big book meliputi: a) Penyebab terjadinya bencana banjir, melalui pengenalan materi ini bertujuan agar anak dapat mengetahui situasi bahaya yang ada di kehidupan sehari- hari mereka yaitu banjir, sehingga diharapkan ketika mengenali penyebab dari banjir yang disesbabkan oleh alam dan manusia. Hal ini bertujuan agar mereka mampu melakukan pencegahan sejak dini agar tidak terjadi banjir seperti tidak membuang sampah di sungai; b) Akibat yang ditimbulkan dari banjir meliputi penyakit apa saja yang sering muncul karena banjir. Hal ini bertujuan untuk mengenalkan bahwa menjaga kesehatan diri sangat penting ketika terjadi banjir agar tidsk timbul penyakit. Selain itu mengetahui resiko kehilangan harta serta keluarga agar anak mampu mengenali perasaan sedih dan melakukan penyelamatan terutama bagi diri sendiri atau orang lain; c) Persiapan sebelum terjadi bencana banjir dengan menjaga kebersihan lingkungan sebagai bentuk upaya dalam mencegah terjadinya banjir meliptui membersihkan saluran air dari sampah secara rutin dan membuang sampah pada tempatnya dimanapun anak berada. Selain itu, menjaga kebersihan saat setelah banjir bertujuan untuk mengenalkan anak bagaimana cara- cara membersihkan rumah setelah banjir, mengeringkan perabotan rumah dan mengeringkan peralatan listrik ketika terendam banjir; d) Pengetahuan dasar saat terjadi bencana banjir terdiri dari kebutuhan saat menghadapi banjir. Hal ini bertujuan untuk mengenalkan kepada anak apa saja yang diperlukan saat banjir meliputi perlengkapan, peralatan penyelamatan (tas siaga banjir). Sikap tanggung jawab atas keselamatan keluarga dan diri sendiri serta barang berharga melalui tindakan kecil yang bersifat penting digambarkan dengan mematikan saklar listrik dan menghubungi pihak yang digunakan sebagi tempat pelapor ketika air meninggi; e) Pengetahuan dasar terkait dengan lingkungan sosial agar anak-anak mengenali pihak-pihak yang digunakan sebagai tempat pelaporan kerugian saat setelah banjir seperti RT/Kepala Desa.

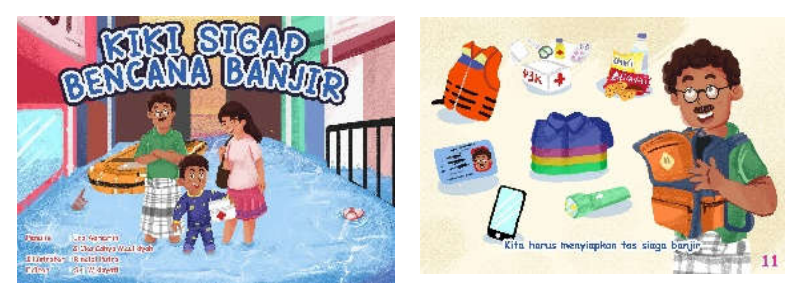

Gambar 1. Hasil Pengembangan Media Big Book

Validator materi dan media memvalidasi desain pengembangan. Selanjutnya, validasi tersebut melalui proses perbaikan dan memperoleh nilai persentase dari ahli media sebesar 
Eka Cahya Maulidyah, Ira Agrestin (Pengembangan Media Big Book)

95,6\% termasuk kriteria sangat layak. Hal ini dibuktikan dari hasil penilaian uji validasi pengembangan media big book terhadap pengetahuan banjir pada anak usia 5-6 tahun. Uji validasi media terdiri dari 4 aspek meliputi: 1) Edukatif berkaitan dengan kesesuaian gambar dengan materi, kelogisan materi dan keruntutan gambar produk media big book; 2) Desain buku meliputi kesesuaian ukuran, pemilihan bahan dan ilustrasi gambar; 3) Kebahasaan meliputi penggunaan ejaan yang sesuai dengan PUEBI, penggunaan kalimat yang tidak berbelit dan pemilihan kata yang mudah dipahami oleh anak; 4) Teknik penyajian berkaitan dengan proses atau cara penggunaan media big book meliputi kesederhanaan gambar yang disajikan, kemenarikan media berkaitan pemilihan gambar pada bagian layout atau cover, pemilihan warna, keterpaduan gambar dengan isi cerita yang berkaitan dengan banjir. Selain itu, sifat kepraktisan atau kemudahan penyimpanan dan pemindahan serta tingkat keterbacaan berkaitan dengan ukuran gambar, tata letak gambar dan penempatan objek bersifat proporsional (seimbang). Adapun sumber yang digunakan dalam uji validasi media bersumber dari penelitian Asfarina (2018) tentang Pengembangan Media Buku Cerita "Jojo Bernai Ke Toilet" dalam Pembelajaran Toilet Training pada Anak Usia Dini yang telah di modifikasi sesuai dengan kebutuhan penelitian.

Selanjutnya, uji validasi isi oleh ahli materi mengenai pengembangan materi banjir untuk anak usia 5-6 tahun pada media big book. Uji validasi terkait dengan materi dalam media big book terdiri dari tiga indikator meliputi: (1) resiko bencana banjir terdiri dua sub indikator yakni pengetahuan dan pemahaman, (2) kesiapsiagaan menghadapi bencana banjir terdiri dari 2 sub indikator yaitu kesiapsiagaan dan rencana tanggap darurat dan (3) pasca bencana banjir meliputi tindakan pasca bencana. Penilaian pada uji validasi materi banjir menggunakan skor 1,2,3,4. Berdasarkan hasli penilaian uji validasi materi memperoleh nilai persentase dari ahli materi sebesar $86,1 \%$ termasuk kriteria sangat layak. Sumber yang digunakan uji validasi materi di modifikasi sesuai dengan kebutuhan penelitian, yakni bersumber dari Peraturan Menteri Pendidikan No.137 Tahun 2014 \& penelitian oleh Purwoko (2015: 81-83) tentang Pengembangan Media Buku Cerita "Jojo Bernai Ke Toilet" dalam Pembelajaran Toilet Training pada Anak Usia Dini

Menurut Setiyaningsih \& Syamsudin (2014) kriteria produk di terima apabila hasil pengembangan produk media big book termasuk kategori layak, jika sesuai dengan kategori kualitas produk media big book yang telah ditetapkan yaitu setiap aspek yang di nilai dalam produk penelitian yang dikembangkan layak apabila semua penilai menilai kualitas produk minimal dengan kategori cukup layak. Maka media big book dianggap layak sebagai media 
pembelajaran baik dari tampilan maupun kulitas produk. Saran perolehan persentase para ahli yang telah melakukan penilaian tertera pada gambar 2 dan 3 berikut ini:

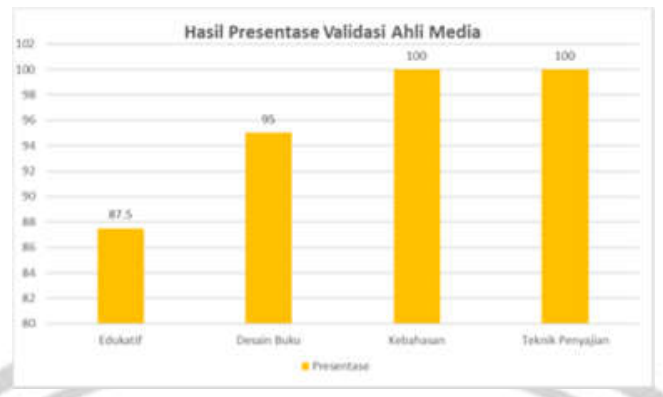

Gambar 2. Diagram Validasi Ahli Materi

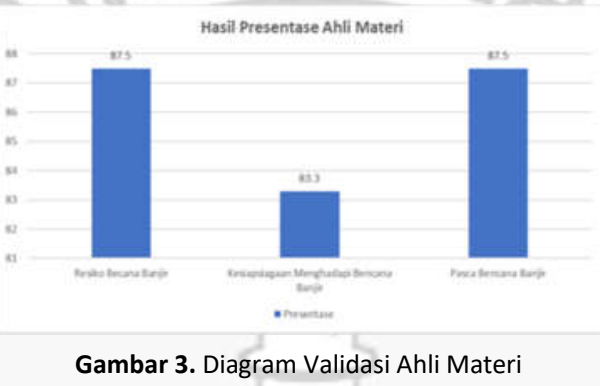

Berdasarkan hasil uji validasi oleh ahli media dan ahli materi untuk mengetahui kelayakan produk media big book memperoleh hasil bahwa media big book terhadap pengetahuan bencana banjir pada anak usia 5-6 tahun kategori sangat layak. Selanjutnya, dilakukan pemberian angket kepada 10 guru PAUD yang telah memenuhi kriteria untuk memberikan masukan dan saran agar penggunaan media big book lebih sesuai secara praktis. Adapun persentase perolehan guru tertera pada gambar 4, sebagai berikut:

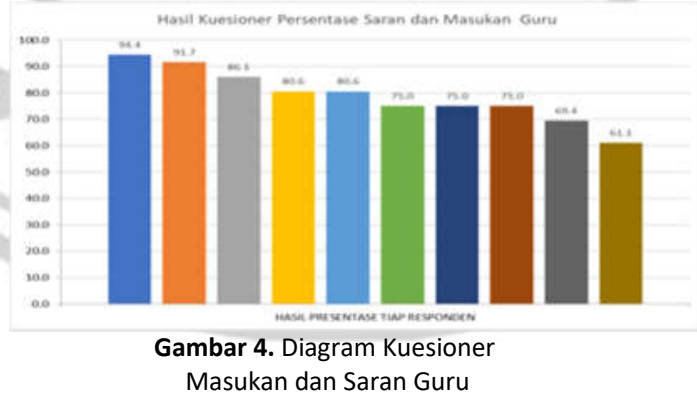

Pengembangan media big book yang telah dilakukan memperoleh hasil penilaian dari sampel 1 sejumlah 94,4\%, sampel 2 sejumlah 91,7\%, sampel 3 sejumlah $86,1 \%$, sampel 4 sejumlah $80,6 \%$, sampel 5 sejumlah $80,6 \%$, sampel 6 sejumlah $75 \%$, sampel 7 sejumlah $75 \%$, sampel 8 sejumlah 75\%, sampel 9 sejumlah $69,4 \%$ dan sampel 10 sejumlah $61,1 \%$.

Berdasarkan perhitungan menggunakan rumus data kuantitatif dengan menyesuaikan pada persentase kriteria kelayakan produk media, diperoleh data nilai persentase angket guru. 
Eka Cahya Maulidyah, Ira Agrestin (Pengembangan Media Big Book)

Data nilai persentase selanjutnya dicari rerata keseluruhannya dari 10 sampel penelitian yang telah ditentukan. Diperoleh nilai persentase sebesar 78,9 \%, termasuk pada kriteria layak. Maka, dapat disimpulkan media big book layak untuk pembelajaran berkaitan dengan pengetahuan banjir.

Data deskriptif berupa masukan dan saran dari 10 guru PAUD di antaranya media big book terhadap pengetahuan bencana banjir pada anak sudah sangat bagus dan cocok untuk pembelajaran bertema banjir. Namun dalam penyajian warna gambar terutama pada warna kulit tokoh agar diperhatikan, sehingga menarik perhatian anak. Guru mendapatkan inovasi dalam memberikan pengetahuan banjir pada anak dengan cara yang menyenangkan. Selain itu, media big book dapat dikembangkan lebih inovatif baik dari tema maupun penyajian agar lebih praktis.

\section{Pembahasan}

Penelitian ini mengembangkan produk berupa media pembelajaran big book bertema banjir. Media big book digunakan dengan tema pembelajaran yang dapat digunakan di lembaga PAUD yakni gejala alam berkaitan dengan pengetahuan banjir. Hal ini sesuai dengan pendapat Colville-hall \& Oconnor (2006) yang menyatakan bahwa big book digunakan pada kelas awal, dimana topik dan isinya dapat di sesuaikan berdasarkan minat anak dan tema pembelajaran. Salah satu tema yang di pilih dalam mengembangkan media big book adalah banjir. Tema banjir di pilih karena meningkatnya tren pembangunan di perkotaan berdampak pada perubahan tata guna lahan dan lingkungan. Hal ini menyebabkan terjadinya penurunan terhadap kualitas ekosistem, sehingga terjadi banjir. Beberapa wilayah perkotaan Surabaya, kondisi banjir menjadi bagian dari kehidupan sehari- hari anak, dimana kejadian tersebut berlangsung lama dan telah menjadi kejadian rutin. Hal ini di sejalan dengan penjelasan Melani (2020) melalui Kepala Badan Penanggulan Bencana dan Perlindungan Masyarakat (BPB Linmas) dan wakil DPRD Surabaya bahwa banjir yang terjadi karena sampah yang di buang sembarangan, sehingga, mengganggu pelaluan air di Jalan Mojopahit Surabaya dan lokasi lainnya. Oleh karena itu, dihimbau kepada masyarakat untuk tidak buang sampah sembarangan. Oleh karena itu, penelitian ini memfokuskan pada pengetahuan banjir anak, mengingat banjir menjadi bagian yang tidak lepas dari kehidupan anak di perkotaan.

Penggunaan media big book diharapkan dapat menumbuhkan perilaku atau mental sadar bencana banjir yang diwujudkan melalui pemahaman akan bencana itu sendiri, sejalan dengan UU No. 24 Tahun 2007 menyatakan bahwa kesiapsiagaan bencana merupakan proses membentuk individu dari aspek pengetahuan, sikap, dan keterampilan menghadapi ancaman 
Eka Cahya Maulidyah, Ira Agrestin (Pengembangan Media Big Book)

yang terdiri dari tindakan pencegahan dan penanggulangan guna menumbuhkan perilaku atau mental sadar terhadap bencana (mengerti dan memahami tentang bencana itu sendiri). Salah satu peningkatan pengetahuan bencana banjir meliputi kesiapsiagaan tentang bencana banjir meliputi persiapan sebelum banjir, kesiapsiagaan saat terjadi banjir dan tindakan pasca bencana banjir.

Pada penelitian ini media big book bertema banjir dikembangkan menjadi lebih sederhana dari segi isi, karena disesuaikan dengan Peraturan Menteri Pendidikan No. 137 Tahun 2014 tentang Standar Nasional Pendidikan Anak Usia Dini. Standar pencapaian anak usia 5-6 tahun yaitu mengetahui situasi yang membahayakan diri. Hal tersebut sesuai dengan Purwani \& Fridani (2019) pendidikan siaga bencana sebagai upaya menumbuhkan jalan mental sadar bencana diwujudkan melalui pendidikan sejak dini.

Tujuan dari pengembangan media big book ini untuk menjawab rumusan masalah yaitu: (1) mengetahui desain pengembangan produk media big book dan (2) mengetahui kelayakan pengembangan media big book terhadap pengetahuan bencana banjir pada anak usia 5-6 tahun. Komponen dalam media big book meliputi penyangga media, gambar, dan isi materi pada media big book serta dilengkapi buku pedoman. Media big book"Kiki Sigap Bencana Banjir" dibuat dengan ukuran A3 dengan jumlah halaman big book 18 halaman terdiri atas cover dan isi cerita. Media big book ini dibuat menyerupai kalender meja, sehingga di spiral kawat dengan penyangga karton. Dengan demikian, memudahkan guru saat menggunakan media di kelas. Media big book dicetak menggunakan art paper dove di laminasi.

Media big book ialah media adalah buku cerita yang memiliki beragam ukuran mulai dari A3, A4, A5 atau seukuran koran dengan gambar penuh warna, berisikan kalimat sederhana yang direpresentasikan melalui gambar-gambar. Selain itu, topik dapat disesuaikan dengan minat dan tema pembelajaran anak. Materi tentang banjir di sederhanakan sesuai dengan anak baik dari sisi gambar atau kalimat, agar lebih mudah dipahami. Manfaat dari big book belajar mengenal dan mengidentifikasi segala sesuatu yang berkaitan dengan pembelajaran banjir. Disamping itu, dengan ukuran gambar dan tulisan yang besar, sehingga media big book dapat menjangkau seluruh anak di kelas dari sisi keterbacaan hal ini mendukung pernyataan Nambiar (1993) bahwa ukuran dan kejelasan ilustrasi membantu memastikan semua anak di kelas dapat fokus pada buku dari kejauhan setidaknya 15 kaki.

Media big book memiliki kelebihan diantaranya sebagai media pembelajaran memiki ukuran yang lebih besar, pola kalimat dan alur yang sederhana sesuai dengan anak-anak. Disamping itu, topik dapat di sesuaikan dengan minat dan tema pembelajaran di kelas, 
Eka Cahya Maulidyah, Ira Agrestin (Pengembangan Media Big Book)

sehingga guru memiliki kesempatan untuk melakukan tanya jawab terkait topik yang disajikan agar semakin berkembang dengan melibatkan imajinasi dan pengalaman anak.

Selain memiliki kelebihan, penelitian ini memiliki kekurangan yakni tidak dapat dilakukan secara langsung di TK karena bertepatan dengan covid-19. Maka kelima tahap model ADDIE, hanya dilakukan sebatas pada pengembangan (development). Namun, solusi yang dapat digunakan dengan membagikan kuisioner secara online beserta media big book dalam bentuk format video.

\section{PENUTUP}

\section{Simpulan}

Pengembangan produk media big book terhadap pengetahuan banjir pada anak usa 5-6 tahun yang telah dilakukan sesuai dengan prosedur tahap ADDIE dapat disimpulkan bahwa:

1. Desain pengembangan media big book terhadap pengetahuan bencana banjir berukuran A3 dengan mempertimbangkan segi keterbacaan. Jenis kertas yang digunakan art paper dove laminasi dan berjumlah 18 halaman. Media big memuat materi tentang penyebab dan akibat banjir, persiapan sebelum, saat dan sesudah banjir. Tampilan media big book menampilkan tokoh Kiki bersama ayah dan ibu saat banjir dan membawa perlengkapan menghadapi banjir. Warna yang dipilih menggunakan warna yang cerah dan lembut agar menarik perhatian anak. Jenis huruf yang digunakan comic sains $m$, sedangkan bahasa yang digunakan bersifat sederhana dan efektif. Selain itu, media big book memiliki kemudahan dalam penyimpanan dan pemindahan.

2. Pengembangan media big book telah melalui uji validasi oleh ahli materi dan ahli materi untuk memperoleh kelayakan terhadap produk media. Hasil menunjukkan produk media termasuk kategori sangat layak dapat digunakan sebagai media pembelajaran. Selain itu, masukan dan saran dari 10 guru PAUD termasuk kategori layak, sehingga sesuai dengan tujuan penelitian bahwa media big book sangat layak terhadap pengetahuan bencana banjir pada anak.

\section{Saran}

Berdasarkan simpulan di atas mengenai penelitian dan pengembangan yang menghasilkan produk media big book, adapun beberapa saran antara lain:

1. Bagi peneliti selanjutnya, pengembangan media big book terhadap pengetahuan bencana banjir pada anak usia 5-6 tahun dapat digunakan sebagai acuan penelitian selanjutnya sampai pada tahap evaluasi serta dikembangkan inovasi big book dalam berbagai tema. 
Eka Cahya Maulidyah, Ira Agrestin (Pengembangan Media Big Book)

2. Bagi guru, hendaknya memberikan fasilitas pembelajaran yang dapat menunjang pengetahuan banjir pada anak melalui pengadaan media pembelajaran dengan tema dan topik yang lebih berkembang dan inovatif.

\section{DAFTAR PUSTAKA}

Achmad Yurianto. (2016). SUDAH SIAPKAH KITA MENGHADAPI BANJIR? Buku

Penanggulangan Krisis Kesehatan Untuk Anak Sekolah (F. Astika \& A. R. Maulana (Eds.)).

Pusat Krisis Kesehatan Kementrian Kesehatan Republik Indonesia.

Adam, S., \& Syastra, M. T. (2015). Pemanfaatan Media Pembelajaran Berbasis Teknologi Informasi Bagi Siswa Kelas X SMA Ananda Batam. CBIS Journal, 3(2), 78-90.

Andini, R. (2020). Pengembangan Buku Cerita (Big Book) Dalam Mengembangkan Karakter Anak Usia Dini. Universitas Islam Negeri Raden Intan Lampung.

Arifianti, Y. (2012). Buku Mengenal Tanah Longsor Sebagai Media Pembelajaran Bencana Sejak Dini (Issue 57).

Asfarina, I. E. (2018). Pengembangan Media Buku Cerita “Jojo Bernai Ke Toilet” dalam Pembelajaran Toilet Training pada Anak Usia Dini. Universitas Jember.

Ayu, D. P., Iriyanto, T., \& Twinsari, R. D. (2020). Media Big Book Portable berbasis Audio-visual dalam Pembelajaran Tematik pada Anak usia 4-5 tahun. Jurnal Pendidikan Anak Usia Dini, $3(1), 18-27$.

Bidang, D. K. T. (2003). Undang-undang sistem pendidikan nasional. Simkeu.Kemdikbud.Go.Id. https://simkeu.kemdikbud.go.id/index.php/peraturan1/8-uu-undang-undang/12-uu-no-20-tahun2003-tentang-sistem-pendidikan-nasional

Colville-hall, S., \& Oconnor, B. (2006). Using Big Books : A Standards-Based Instructional Approach for Foreign Language Teacher Candidates in a PreK-12 Program. Foreign Language Annals, 3.

Fatriani, A., \& Samadhy, U. (2018). Pengembangan Media Big Book Terhadap Keterampilan Membaca Permulaan Dengan Metode Suku Kata. Joyful Learning Journal, 7(1), 1-9.

Hanifah, A. (2017). Pengembangan Media Pop Up Book Materi Bencana Banjir Untuk Meningkatkan Pemahaman Konsep Siswa Kelas I MIN Sukosewu Gandusari Kab. Blitar. Universitas Islam Negeri Maulana Malik Ibrahim Malang.

Harsono, F. H. (2019). Buku Saku Kesadaran Bencana untuk Anak- anak Penuh Gambar Ilustrasi, Kenapa? Www.Liputan6.Com. https://liputan6.com/health/read/4035620/buku-saku-kesadaranbencana-untuk-anak-anak-penuh-ilustrasi-gambar-kenapa

Kiromi, H. I., \& Fauziah, Y. P. (2016). Jurnal Pendidikan dan Pemberdayaan Masyarakat. Jurnal 
Pendidikan Dan Pemberdayaan Masyarakat, 3, 48-59.

Maulidiyah, E. C., \& Chamim, N. M. (2020). Stimulasi Kemampuan Mengenal Lambang Bilangan Anak Melalui Media Prisma. Jurnal PAUD Teratai, 09.

Melani, A. (2020). Ini Penyebab Banjir Terjadi di Surabaya. Www.Liputan6.Com.

https://m.liputan6.com/surabaya/read/415689/ini-penyebb-banjir-terjadi-di-surabaya

Mujiani, D. (2016). Pengaruh Media Pembelajaran Dan Kecerdasan Logis Matematis Terhadap Hasil Belajar Matematika Siswa. Jurnal Pendidikan Dasar, 7(2), 199.

Nambiar, M. (1993). Early Reading Instruction - Big Books in the ESL Classroom**. Early Reading Instruction - Big Books in the ESL Classroom, XXII(October), 1-9.

Novita Rahmawati Aditya NPM. (2020). Pengembangan Media Big Book Berbasis Agama Dalam Mengembangkan Kecerdasan Spiritual Anak Usia Dini Usia 5-6 Tahun di Taman KanakKanak. Universitan Islam Negeri Raden Intan Lampung.

Nurlaela, L. (2018). Pengembangan Media Pembelajaran Busy Book dalam Meningkatkan Kemampuan Bahasa Anak Usia Dini di Playgroup Islam Bina Balita Way Halim Bandar Lampung Tahun Ajaran 2017/2018. Universitas Islam Negeri Raden Intan.

Peraturan Menteri Pendidikan No.137. (2014). Menteri Pendidikan dan Kebudayaan Republik Indonesia.

Pudjawan, K. (2015). Pengembangan Buku Ajar Model Penelitian Analyze Implement Evaluate Design Develop. Seminar Nasional Riset Inovatif IV, 208-216.

Purwani, A., \& Fridani, L. (2019). Jurnal Obsesi : Jurnal Pendidikan Anak Usia Dini Pengembangan Media Grafis Untuk Meningkatkan Siaga Bencana Banjir. Jurnal Obsesi: Jurnal Pendidikan Anak Usia Dini, 3(1), 55-67. https://doi.org/10.31004/obsesi.v3i1.142

Purwoko, A. (2015). Pengaruh Pengetahuan dan Sikap Tentang Resiko Bencana Banjir Terhadap Kesiapsiagaan Remaja Usia 15-18 Tahun dalam Menghadapi Bencana Banjir di Kelurahan Pedurungan Kidul Kota Semarang. Universitas Negeri Semarang.

Pusat Data Informasi Komunikasi BNBP. (2020). Sebaran Kejadian Bencana Alam 1 Januari - 16 November 2020. Twitter. https://twitter.com/BNPB_Indonesia/status/1328289169316069384

R.Hadianto Wardjaman dkk. (2018). Buku Panduan Kesiapsiagaan Bencana Untuk Keluarga (A. A. Harianto, J. Tarigan, \& R. T. Thamrin (Eds.); Hari Kesia). Direktorat Badan Nasional Penanggulangan Bencana.

Sari, K. B. (n.d.). Desain pembelajaran model addie dan implementasinya dengan teknik jigsaw. Prosiding Seminar Nasional Pendidikan : Tema "Desain Pembelajaran Di Era ASEAN 
Eka Cahya Maulidyah, Ira Agrestin (Pengembangan Media Big Book)

Economic Comunity (AEC) Untuk Pendidiikan Indonesia Berkemajuan” Fakultas Keguruan

Dan Ilmu Pendidikan Universitas Muhammadiyah Sidoarjo., 87-102.

Saroinsong, W. P., Farikhah, W. A., \& Widayati, S. (2020). Media Buku Saku Berbasis Motorik Halus Untuk Anak Pra Sekolah. Al- Hikmah: Indonesian Journal of Early Childhood Islamic Education, 4(1), 67-83.

Setiyaningsih, G., \& Syamsudin, A. (2014). Pengembangan Media Big Book Untuk Meningkatkan Kemampuan Literasi Anak Usia 5-6 Tahun. Jurnal Pendidikan Dan Kebudayaan, 2011, 19-28. Sugiyono. (2016). Metode Penelitian Kuantitatif, Kualitatif dan R\&D (Cetakan ke). ALFABETA. Susanti, Saragih, A., \& Pulungan, A. H. (2020). Designing Big Book as Media for Learning English Vocabulary. 4th Annual International Seminar on Transformative Education and Educational Leadership (AISTEEL 2019), 384(Aisteel), 174-178. https://doi.org/10.2991/aisteel-19.2019.37

Wibowo, B., Vebrianti, ika, Pertiwi, N. R., Widiyatmoko, Y., \& Nursa'ban, M. (2017). Disaster Mitigation Pop Up Book Sebagai Media Pembelajaran Mitigasi Bencana Berbasis Kearifan Lokal Bagi Siswa Sekolah Dasar. Geomedia, 15, 61-74. 